УДК 340.14

DOI: https://doi.org/10.47567/bomivit.1-3.2020.05

О. О. Галус, кандидат юридичних наук доцент кафедри конституційного адміністративного та фінансового права Хмельницького університету управління та права імені Леоніда Юзькова elenhalus@meta.ua

ORCID: https:/ / orcid.org/ 0000-0002-5474-3323

М. М. Баймуратов, кандидат юридичних наук аспірант кафедри конституційного адміністративного та міжнародного права Маріупольского державного університету Заступник начальника юридичного відділу Головного управління ДФС в Одеській області Baymuratov.maksym@gmail.com

ORCID: https/ / orcid.org/0000-0002-5013-9065

\title{
ДО ПИТАННЯ ПРО ПОНЯТТЯ ТА КЛАСИФІКАЦЮЮ МУНІЦИПАЛЬНО-ПРАВОВИХ АКТІВ БЕЗПОСЕРЕДНЬОГО НАРОДОВЛАДДЯ
}

O. O. Halus, PhD in Law Associate Professor of the Department of constitutional, administrative and financial law Leonid Yuzkov Khmelnytskyi University of Management and Law elenhalus@meta.ua ORCID: https:/ / orcid.org/ 0000-0002-5474-3323

\section{M. Baimuratov,} PhD in Law

Post-graduate student of the Department of constitutional, administrative and international law Mariupol State University Deputy head of legal department Operational Directorate of the General Directorate of the DFS in Odesa Oblast Baymuratov.maksym@gmail.com ORCID: https/ / orcid.org/0000-0002-5013-9065 


\section{ON THE QUESTION OF THE CONCEPT AND CLASSIFICATION OF MUNICIPAL LEGAL ACTS OF DIRECT PEOPLE'S RULE}

В статті обгрунтовано виділення муніципально-правових актів безпосереднього народовладдя як різновиду муніципально-правових актів. Запропоновано розуміти під муніципально-правовим актом безпосереднього народовладдя рішення нормативно-правового або індивідуально-правового характеру, прийняте безпосередньо членами територіальної громади 3 метою вирішення питань місцевого значення в межах Конституції та законів України. Здійснено поділ муніципально-правових актів безпосереднього народовладдя за характером приписів на нормативні, індивідуальні та змішані. Визначено, що змішані муніципально-правові акти безпосереднього народовладдя містять як нормативні, так і індивідуальні правові приписи. До них можна віднести прийняття на загальних зборах громадян рішення про самооподаткування тощо. Враховуючи практику проведення в Україні місцевих референдумів запропоновано класифікацію рішень місцевих референдумів: за юридичною силою рішення місцевих референдумів поділяються на імперативні та диспозитивні; за підставами проведення місцевих референдумів рішення поділяються на: обов'язкові, факультативні; за часом проведення місцевого референдуму його рішення можуть бути: дорадчі, ратифікаційні; за предметом референдуму рішення місцевих референдумів можуть бути із адміністративно-територіальних питань, благоустрою територій, земельних питань, зміни базового рівня місцевого самоврядування, найменування населених пунктів, припинення повноважень сільського, селищного, міського голови, сільської, селищної, міської ради.

Визначено поняття та види окремих муніципально-правових актів безпосереднього народовладдя, зокрема рішень місцевих референдумів та рішень загальних зборів громадян за місцем проживання.

Ключові слова: муніципально-правовий акт, муніципально-правовий актів безпосереднього народовладдя, рішення місцевого референдуму, рішення загальних зборів громадян за місцем проживання.

The article substantiates the allocation of municipal legal acts of direct democracy as a kind of municipal legal acts. It is proposed to understand by a municipal legal act of direct democracy a decision of normative-legal or individual-legal nature, adopted directly by members of the territorial community in order to resolve issues of local significance within the Constitution and laws of Ukraine. The division of municipal legal acts of direct democracy by the nature of prescriptions into normative, individual and mixed. It is determined that mixed municipal legal acts of direct democracy contain both normative and individual legal prescriptions. These include the adoption of a decision on self-taxation at general meetings of citizens, and so on. Taking into account the practice of holding local referendums in Ukraine, the classification of decisions of local referendums is proposed: according to the legal force, decisions of local referendums are divided into imperative and dispositive; on the basis of local referendums, decisions are divided into: mandatory, optional; at the time of the local referendum, its decisions may be: advisory, ratification; on the subject of the referendum, local referendum decisions may be on administrativeterritorial issues, landscaping, land issues, changes in the basic level of local self- 
government, names of settlements, termination of powers of village, town, city, village, town, city council.

The concepts and types of separate municipal legal acts of direct democracy, in particular decisions of local referendums and decisions of general meetings of citizens at the place of residence are defined.

Keywords: municipal-legal act, municipal-legal acts of direct democracy, decision of local referendum, decision of general meeting of citizens at the place of residence.

Постановка проблеми. Із впровадженням в Україні реформи децентралізації актуальним стає належне нормативно-правове регулювання порядку вирішення територіальними громадами, в тому числі і об'єднаними, питань місцевого значення безпосередньо. До сих пір неврегульованої залишається така пріоритетна форма безпосереднього народовладдя на місцевому рівні як місцевий референдум. Не отримали належного регулювання на законодавчому рівні і загальні збори громадян за місцем проживання, які приймають рішення, обов'язкові до виконання на відповідній території.

Аналіз останніх досліджень і публікацій. Дослідженню проблем місцевої демократії (народовладдя) ії окремих форм були присвячені роботи О. В. Батанова, В. В. Комарової, О. Г. Мурашина, Л. О. Нудненко, В. Ф. Погорілка, О. В. Скрипнюка, та інших вчених. Питанню ж муніципально-правових актів в цілому, та муніципально-правовим актам безпосереднього народовладдя зокрема, увага практично не приділялася. Заслуговує на увагу монографічне дослідження актів прямого народовладдя О. Г. Мурашина, в якому окрему увагу автор приділяв аналізу актів прямого народовладдя місцевого рівня [2].

Метою статті $€$ визначення поняття та здійснення класифікації муніципально-правових актів безпосереднього народовладдя та їх окремих видів.

Виклад основного матеріалу. Муніципально-правові акти безпосереднього народовладдя є різновидом муніципально-правовими актів, під якими доцільно розуміти рішення нормативно-правового або індивідуально-правового характеру, прийняті безпосередньо членами територіальної громади або уповноваженими органами чи посадовими особами місцевого самоврядування 3 метою вирішення питань місцевого значення в межах Конституції та законів України [1, с. 31].

Муніципально-правові акти залежно від суб'єктів їх прийняття доцільно поділяти на правові акти органів та посадових осіб місцевого самоврядування та муніципально-правові акти безпосереднього народовладдя.

Термін «муніципально-правових актів безпосереднього народовладдя» майже не вживається. О. Г. Мурашин в своєму монографічному дослідженні визначав акти прямого народовладдя як юридичні акти, які грунтуються на безпосередній участі населення у вирішенні питань державного і суспільного життя, на прямому волевиявленні при виробленні, прийнятті владних настанов, а також участі у їх реалізації і здійсненні контролю [2, с. 31-32]. Місцевий акт прямого народовладдя О. Г. Мурашин пропонував визначати як прийняте безпосередньо населенням відповідно до вимог законності рішення, яке установлює, змінює або скасовує норми права, персонально-конкретні приписи, рекомендації з метою виконання місцевих завдань державного, господарського i соціально-культурного будівництва. Основним місцевим актом прямого народовладдя вказаний автор визначає рішення [2, c. 107]. 
До муніципально-правових актів безпосереднього народовладдя можна віднести рішення місцевих референдумів, рішення загальних зборів громадян за місцем проживання, рішення про самооподаткування тощо. На сьогодні в законодавстві України існує прогалина щодо законодавчого регулювання цих видів муніципально-правових актів.

На нашу думку, під муніципально-правовим актом безпосереднього народовладдя варто розуміти рішення нормативно-правового або індивідуальноправового характеру, прийняте безпосередньо членами територіальної громади 3 метою вирішення питань місцевого значення в межах Конституції та законів України.

Що стосується класифікації муніципально-правових актів безпосереднього народовладдя, значний інтерес викликає запропонований О. Г. Мурашиним поділ актів прямої демократії за юридичними властивостями і особливостями приписів на нормативні і ненормативні (індивідуально-конкретні). Серед нормативних актів прямого народовладдя автор виділяє нормативно-допоміжні та змішані акти [2, с. 108].

Взявши за основу класифікацію, запропоновану О. Г. Мурашиним, можна запропонувати поділ муніципально-правових актів безпосереднього народовладдя за характером приписів на нормативні, індивідуальні та змішані.

Нормативні муніципально-правові акти безпосереднього народовладдя містять правові норми загальнообов'язкового характеру, розраховані на багаторазове використання.

Індивідуальні муніципально-правові акти безпосереднього народовладдя носять правозастосовчий характер. До них можна віднести рішення місцевого референдуму про підтримку добровільного об'єднання територіальних громад; рішення загальних зборів про дострокове припинення повноважень органу самоорганізації населення; рішення місцевих референдумів про дострокове припинення повноважень сільської, селищної, міської ради, сільського, селищного, міського голови тощо.

Змішані муніципально-правові акти безпосереднього народовладдя містять як нормативні, так і індивідуальні правові приписи. До них можна віднести прийняття на загальних зборах громадян рішення про самооподаткування тощо.

Проаналізуємо детальніше окремі види муніципально-правових актів безпосереднього народовладдя.

Рішення місцевих референдумів є найвищим актом в системі муніципальноправових актів безпосереднього народовладдя. Місцевий референдум виступає формою вирішення територіальною громадою питань місцевого значення шляхом прямого волевиявлення. Предметом місцевого референдуму може бути будь-яке питання, віднесене Конституцією України, цим та іншими законами до відання місцевого самоврядування. На місцевий референдум не можуть бути винесені питання, віднесені законом до відання органів державної влади.

Рішення, прийняті місцевим референдумом, є обов'язковими для виконання на відповідній території. Варто погодитися із О. В. Скрипнюком, який зазначає, що рішення місцевого референдуму $\epsilon$ нормативно-правовим актом місцевого самоврядування, обов' язковим до виконання на відповідній території [4, с. 42].

Згідно із п.20 ч.1 ст.92 Конституції України порядок організації та проведення виборів та референдумів визначаються виключно законами України. 
Відповідно до ч.5 ст.7 Закону України «Про місцеве самоврядування в Україні» порядок призначення та проведення місцевого референдуму, а також перелік питань, що вирішуються виключно референдумом, визначаються законом про референдуми.

На сьогодні законодавче регулювання порядку проведення місцевих референдумів відсутнє, оскільки із прийняттям Закону України «Про всеукраїнський референдум» від 06.11.2012 р. втратив чинність Закон України «Про всеукраїнський та місцеві референдуми» від 03.07.1991 р., який регулював порядок організації та проведення місцевих референдумів.

Враховуючи практику проведення з 1991 року по 2012 рік в Україні місцевих референдумів, можна запропонувати наступну класифікацію рішень місцевих референдумів:

1. За юридичною силою рішення місцевих референдумів поділяються на імперативні, які мають вищу юридичну силу, є остаточними та обов'язковими для виконання на відповідній території; диспозитивні, які не мають обов'язкової юридичної сили, але повинні враховуватися органами місцевого самоврядування при прийнятті відповідних рішень.

2. За підставами проведення місцевих референдумів рішення поділяються на: обов'язкові, коли референдуми проводяться для вирішення питань, які згідно із Конституцією та законами України можуть бути розв'язані тільки шляхом референдуму; факультативні - в разі вирішення питань, які згідно із Конституцією та законами України можуть вирішуватися і в інший спосіб (наприклад, рішення про підтримку об'єднання територіальних громад, рішення про дострокове припинення повноважень сільського, селищного, міського голови тощо).

3. За часом проведення місцевого референдуму його рішення можуть бути: дорадчі - у випадку проведення місцевого референдуму до розгляду проекту акту органом місцевого самоврядування з метою визначення ставлення громадян до нього і мають, як правило, консультативний характер; ратифікаційні - у випадку проведення місцевого референдуму після розгляду проекту акту відповідною місцевою радою, що надає акту відповідної юридичної сили.

4. За предметом референдуму рішення місцевих референдумів можуть бути із адміністративно-територіальних питань, благоустрою територій, земельних питань, зміни базового рівня місцевого самоврядування, найменування населених пунктів, припинення повноважень сільського, селищного, міського голови, сільської, селищної, міської ради.

Рішення місцевих референдумів можна класифікувати i за іншими критеріями, наприклад, за просторово-часовими межами тощо.

Рішення загальних зборів громадян за місцем проживання виступають ще одним видом муніципально-правових актів безпосереднього народовладдя.

Загальні збори громадян за місцем проживання досі залишаються неврегульованими на законодавчому рівні, адже згідно із ч.3 ст.8 Закону України «Про місцеве самоврядування в Україні» порядок проведення загальних зборів громадян за місцем проживання визначається законом та статутом територіальної громади. Однак на сьогодні такий закон відсутній. Порядок проведення зборів громадян за місцем проживання регулюються статутами територіальних громад або положеннями про загальні збори громадян, які є додатками до відповідних статутів територіальних громад. Закон України «Про місцеве самоврядування в Україні» 
обмежується загальним посиланням на мету прийняття статуту, не вказуючи перелік питань, що мають бути врегульовані в ньому. Різні статути територіальних громад по-різному визначають процедуру прийняття рішень загальних зборів, коли їх учасників, можливість зупинення рішень зборів громадян за місцем проживання.

Рішення загальних зборів громадян можна класифікувати за різними підставами. За територією дії рішення загальні збори громадян за місцем проживання можна поділити на: рішення зборів або конференції всієї територіальної громади, тобто жителів села, селища, міста; рішення зборів частини територіальної громади, рішення будинкових, вуличних, квартальних зборів, рішення зборів жителів мікрорайону, району у місті тощо.

За правовими наслідками рішення загальних зборів громадян за місцем проживання поділяються та: імперативні, тобто ті, що прийняті в межах їх компетенції і є обов'язковими до виконання (наприклад, збори громадян, на яких відбуваються вибори органів самоорганізації населення, рішення загальних зборів про самооподаткування); консультативні, тобто рішення, які містять пропозиції щодо роботи органів і посадових осіб місцевого самоврядування і не є обов' язковими для виконання ними, але які повинні розглянути їх у встановленні строки і повідомити населення про результати розгляду (наприклад, збори громадян за місцем проживання з питань місцевої ініціативи тощо).

За підставами проведення загальних зборів громадян за місцем проживання рішення можуть бути: обов'язкові, коли законодавством України або статутами територіальних громад передбачено, що рішення 3 певних питань місцевого значення приймаються виключно загальними зборами (обрання органів самоорганізації населення, самооподаткування, внесення місцевої ініціативи); факультативні, коли збори скликаються за ініціативою не менш як третини громадян, які проживають на відповідній території, для вирішення питань, що відносяться до компетенції місцевого самоврядування.

В юридичній літературі наводяться й інші класифікації рішень загальних зборів, зокрема за засобами проведення виділяють законні і незаконні, за предметом - політичні, економічні, соціальні, культурні, екологічні тощо.

Рішення загальних зборів (конференції), прийняті в межах чинного законодавства України, є обов'язковими для виконання відповідними органами самоорганізації населення та громадянами, які проживають на цій території. Рішення загальних зборів (конференції) враховуються сільською, селищною, міською радою, їх виконавчим комітетом та іншими виконавчими органами, їх посадовими особами у своїй діяльності.

Рішення загальних зборів (конференції) приймаються відкритим або таємним голосуванням більшістю голосів громадян (представників), які присутні на загальних зборах (конференції) та підписуються головою та секретарем зборів.

За результатами загальних зборів (конференції) та ухвалених на них рішень складається протокол у двох примірниках. До протоколу загальних зборів (конференції) додаються матеріали реєстрації їх учасників (список громадян або список представників громадян відповідних територіальних утворень, які були присутніми на зборах (конференції), із зазначенням прізвища, ім'я та по батькові, року народження, адреси реєстрації місця проживання з особистим підписом.

Протокол загальних зборів (конференції) підписується головою та секретарем не пізніше трьох днів після їх проведення та протягом наступного дня один 
примірник (з оригіналом списку громадян, які були присутні на зборах), передається до органу місцевого самоврядування або установи, до компетенції яких належить вирішення питань, що розглядались загальними зборами (конференцією).

Другий примірник протоколу, з копією списку громадян, які були присутні на зборах, засвідченою головою та секретарем загальних зборів (конференції), залишається у ініціаторів скликання загальних зборів (конференції).

Копія протоколу передається до сільської, селищної, міської ради, яка забезпечує розміщення сканованого протоколу зборів (конференції) 3 усіма додатками на офіційному веб-сайті ради протягом п'яти робочих днів 3 дня їх надходження, при цьому вилучає з них персональні дані фізичних осіб.

Рішення загальних зборів (конференції) проводяться в життя сільським, селищним, міським головою, сільською, селищною, міською радою та ії виконавчими органами, органами самоорганізації населення.

До реалізації рішень загальних зборів (конференції) залучаються населення відповідної території, підприємства, організації, установи, які розташовані на відповідній території.

Органи самоорганізації населення зобов'язані регулярно інформувати населення про виконання рішень загальних зборів (конференції) у порядку, встановленому положеннями про них.

До прикладу, в Статуті територіальної громади м. Хмельницького визначається, дію рішень загальних зборів (конференції), прийнятих з порушенням Конституції та законодавства України, може бути зупинено відповідною місцевою радою або іï виконавчим комітетом до вирішення питання про їх законність у судовому порядку. Рішення про зупинення дії загальних зборів (конференції) та подання відповідного звернення до суду відбуваються одночасно, про що письмово протягом не більше п'яти робочих днів повідомляється ініціатор проведення загальних зборів (конференції) [3].

Пропозиції, викладені у протоколі загальних зборів (конференції), розглядаються на найближчому відкритому засіданні сільської, селищної, міської ради та/або ії виконавчого комітету (залежно від того, до кого вони скеровані) за обов' язкової участі ініціаторів загальних зборів (конференції), яким надається слово для виступу.

За результатами проведення засідання органи місцевого самоврядування або ïx посадові особи ухвалюють рішення про врахування, часткове врахування або відхилення рішень загальних зборів (конференції). Рішення органів місцевого самоврядування або їх посадових осіб за результатами розгляду рішень загальних зборів (конференції) протягом п'яти робочих днів 3 дня розгляду надсилається ініціаторам скликання загальних зборів (конференції) та розміщається на офіційному веб-сайті відповідної місцевої ради.

Збори громадян за місцем проживання та конференції представників громадян можуть запровадити місцеві збори на засадах добровільною самооподаткування.

Під самооподаткуванням потрібно розуміти форму залучення на добровільній основі за рішенням зборів громадян за місцем проживання коштів населення відповідної території для фінансування разових цільових заходів соціально-побутового характеру. Самооподаткування деякі автори вважають самостійною формою безпосереднього народовладдя. 
У разі прийняття рішення про самооподаткування в рішенні загальних зборів громадян або конференцій представників обов' язково визначаються:

мета, з якою запроваджується самооподаткування:

термін дії самооподаткування;

територія, на якій запроваджується самооподаткування;

порядок збирання та витрачання коштів населення, які зібрані на засадах самооподаткування;

порядок звітності перед населенням міста про витрачання коштів самооподаткування [3] тощо.

Висновки. Отже, муніципально-правовими актами безпосереднього народовладдя виступають рішення нормативно-правового або індивідуальноправового характеру, прийняті безпосередньо членами територіальної громади 3 метою вирішення питань місцевого значення в межах Конституції та законів України. За характером приписів муніципально-правові акти поділяються на нормативні, індивідуальні та змішані. Вся система муніципально-правових актів безпосереднього народовладдя потребує вдосконалення їx законодавчого врегулювання, визначення їх місця в ієрархії муніципально-правових актів тощо.

Список використаних джерел:

1. Галус О.О. Поняття та види муніципально-правових актів. Конституційноправові академічні студіï. 2017. № 3. С. 26-32.

2. Мурашин О. Г. Акти прямого народовладдя у правовій системі; Нац. акад. внутр. справ України. Київ : Знання, 1999. 183 с.

3. Рішення Хмельницької міської ради про затвердження нової редакції Статуту територіальної громади м. Хмельницького 2017. URL: https://khm.gov.ua/uk/content/statut-terytorialnoyi-gromady-m-hmelnyckogo

4. Скрипнюк О. Місцевий референдум як форма забезпечення реального народовладдя. Вісник Національної академї правових наук України. 2015. № 1. С. $37-44$.

\section{References:}

1. Halus, O. O. (2017). Poniattia ta vydy munitsypalno-pravovykh aktiv [The concepts and types of municipal legal acts]. Konstytutsiino-pravovi akademichni studii [Constitutional and legal academic studies], no. 3, 26-32. [in Ukrainian].

2. Murashyn, O. H. (1999). Akty priamoho narodovladdia u pravovii systemi [Acts of direct democracy in the legal system]. Kyiv. Znannia. [in Ukrainian].

3. The charter of a territorial community of the city of Khmelnitsky. URL: https://khm.gov.ua/uk/content/statut-terytorialnoyi-gromady-m-hmelnyckogo [in Ukrainian].

4. Skrypniuk, O. V. (2015). Mistsevyi referendum yak forma zabezpechennia realnoho narodovladdia [Local referendum as a form of providing real democracy]. Visnyk Natsionalnoi akademii pravovykh nauk Ukrainy [Bulletin of the National Academy of Legal Sciences of Ukraine], no. 1 (80), 37-44. [in Ukrainian]. 